\title{
Reason and rights in global drug control policy
}

\section{Richard Elliott, Joanne Csete, Anita Palepu, Thomas Kerr}

A mong a number of compelling reasons for the international community to reconsider the "war on drugs," the HIV/AIDS epidemic is the most urgent. The prevailing emphasis on law enforcement in drug policy has failed to produce its purported benefits, yet many countries insist on enforcing prohibition and resist the implementation of evidence-based measures to reduce the healthrelated harms of drug use. These policies disregard the available scientific evidence, and in so doing directly contribute to the harms associated with illicit drug use, including the spread of HIV/AIDS. ${ }^{1}$ Moreover, they contravene human rights obligations under international law. Developments in the coming weeks will indicate whether the World Health Organization and the member states of the United Nations can rise to the challenge of mitigating the negative health impacts of global drug control treaties or whether timidity in the face of ideological bullying will prevail.

Roughly 40 million people are infected with HIV worldwide, of whom an estimated 5 million were infected during 2003 alone. ${ }^{2}$ Some 3 million people died of HIV/AIDS last year. ${ }^{2}$ In many settings, opioid dependence and associated sharing of drug injection equipment is a principal factor fuelling the epidemic. ${ }^{3}$ It is estimated that there are over 13 million illicit injection drug users (IDUs) worldwide. ${ }^{4}$ Of the 136 countries that reported injection drug use in 2003, 93 also reported HIV infection among IDUs. ${ }^{5}$ The HIV epidemic is growing exponentially in Eastern Europe and countries of the former Soviet Union; in these regions, IDUs and their sexual contacts account for most new infections. ${ }^{6,7}$ A similar pattern is seen in Asia. ${ }^{8}$ An estimated $10 \%$ of all new HIV infections worldwide are now attributable to injection drug use; this figure rises to $30 \%$ outside Africa. ${ }^{9}$ Although antiretroviral drugs have improved HIV care, access to these drugs is notoriously limited, including in many regions where the epidemic is driven largely by injection drug use. ${ }^{10}$ Even where antiretroviral treatment is available, access for drug users has been particularly poor. ${ }^{1,11}$ In Russia, for example, over $90 \%$ of cumulative HIV cases as reported by government HIV/AIDS programs by 2002 were among IDUs, yet AIDS service programs in Moscow and St. Petersburg reported that none of the patients receiving antiretroviral drugs were IDUs. ${ }^{12}$

Given the major role played by injection drug use in the HIV/AIDS epidemic, opioid substitution therapy, which facilitates both prevention and treatment, is a critical element of a comprehensive response. Access to oral methadone or buprenorphine can reduce or eliminate injection of heroin and the frequently associated sharing of injection equipment. ${ }^{13}$ Clinical studies have demonstrated that access to addiction treatment programs significantly increases uptake of HIV treatment among IDUs. ${ }^{14-20}$ Substitution therapy has been recognized as the most effective treatment for opioid dependence ${ }^{21}$ and has been widely implemented. ${ }^{22}$ Yet opiate substitutes are unavailable or banned in many of the countries where HIV prevalence and incidence are high among IDUs. ${ }^{22}$

Because a significant number of people living with HIV/AIDS are IDUs, current global efforts to scale up access to antiretroviral treatment will necessitate universal access to substitution therapy as a matter of equity and of pragmatism. Proposals to add methadone and buprenorphine to the WHO's Model List of Essential Medicines ${ }^{23}$ will be considered by the WHO's Expert Committee on the Use of Essential Drugs this month. The addition of these drugs to the list would encourage their integration into national health systems, facilitate funding from such mechanisms as the Global Fund to Fight AIDS, Tuberculosis and Malaria, and signal to governments that access to such therapy for drug users must be integrated into HIV prevention and treatment plans. ${ }^{24}$

The international community also faces the larger question of whether it will continue to endorse failed strategies of drug prohibition and law enforcement or finally embrace evidence-based harm-reduction measures such as opioid substitution, syringe exchange and supervised injection facilities. All UN member states have a treaty obligation to cooperate with the UN in solving international health problems and in realizing human rights for all. ${ }^{25}$ The Universal Declaration of Human Rights, reaffirmed by all UN member states for more than 50 years, declares that all people have the right to a standard of living adequate for health and well-being, including access to medical care. ${ }^{26}$ The International Covenant on Economic, Social and Cultural Rights ${ }^{27}$ recognizes the right of all people to enjoy the highest attainable standard of health (Article 12). Furthermore, it requires all parties to the covenant to take steps to "progressively realize" this right "by all appropriate means, including particularly the adoption of legislative measures" (Article 2) and to take the steps necessary to prevent, treat and control epidemic diseases and to create conditions that assure medical services and attention in the event of sickness (Article 12). At the very least this means that countries must not block harm-reduction measures that reduce the spread of HIV among drug users, and that they must facilitate access to health services.

At its upcoming session this month, the UN Commis- 
sion on Narcotic Drugs, the central policy-making body within the UN system with regard to drug control, will be holding a thematic discussion on "HIV/AIDS in the context of drug use." Already, hard-line prohibitionist countries such as the US are preparing to resist interpretations of UN treaties on illicit-drug control that encourage a harm-reduction approach. Among other tactics, the US administration continues to disingenuously cast doubt on the proven benefits of syringe exchange programs, regularly invoking misinterpretations of the Canadian experience in cities such as Vancouver and Montreal. ${ }^{28}$

Canada is bound by the human rights obligations it has undertaken as a member state of the UN, and human rights are stated as a central part of Canadian foreign policy. ${ }^{29,30}$ Canada has implemented a wide range of harm-reduction measures domestically (partly in response to HIV/AIDS), and the declared central objective of our national drug strategy is harm reduction. ${ }^{31,32}$ Canada should therefore play the role of strong global advocate for harm reduction, including at the UN Commission on Narcotic Drugs. This debate needs rational voices informed by public health evidence and a firm commitment to the human rights of all people, including those who are drug dependent.

From the British Columbia Centre for Excellence in HIV/AIDS, St Paul's Hospital (Kerr); the Department of Medicine, University of British Columbia, Vancouver, BC (Palepu); the Canadian HIV/AIDS Legal Network, Toronto, Ont. and Montréal, Que. (Elliott, Csete).

Competing interests: None declared.

\section{References}

1. Wolfe D, Malinowska-Sempruch K. Illicit drug policies and the global HIV epidemic: effects of $U N$ and national government approaches. A working paper commissioned by the HIV/AIDS Task Force of the Millennium Project. New York: Open Society Institute; 2004.

2. Joint United Nations Programme on HIV/AIDS (UNAIDS). Report on the global AIDS epidemic 2004: 4th global report. Geneva: UNAIDS; 2004.

3. Kerr T, Wodak A, Elliott R, Montaner JS, Wood E. Opioid substitution and HIV/AIDS treatment and prevention. Lancet 2004;364:1918-9.

4. Aceijas C, Stimson GV, Hickman M, Rhodes T, United Nations Reference Group on HIV/AIDS Prevention and Care among IDU in Developing and Transitional Countries. Global overview of injecting drug use and HIV infection among injecting drug users. AIDS 2004;18(17):2295-303.

5. World Health Organization. Management of substance abuse: WHO drug injection study. Geneva: WHO; 2003.

6. Joint United Nations Programme on HIV/AIDS (UNAIDS). AIDS epidemic Update: December 2003. Geneva: UNAIDS; 2003.

7. Rhodes T, Sarang A, Bobrik A, Bobkov E, Platt L. HIV transmission and HIV prevention associated with injecting drug use in the Russian Federation. Int 7 Drug Policy 2004;15:1-16.

8. Wodak A, Ali R, Farrell M. HIV in injecting drug users in Asian countries. BM7 2004;32:697-8.

9. Joint United Nations Programme on HIV/AIDS (UNAIDS). Report on the Global HIVIAIDS Epidemic 2002. Geneva: UNAIDS; 2002.

10. World Health Organization (WHO). Scaling up antiretroviral therapy in resource-limited settings: treatment guidelines for a public bealth approach. 2003 revision. Geneva: WHO; 2004.
11. Breaking down barriers: lessons on providing HIV treatment to injection drug users. New York: Open Society Institute; 2004.

12. Central and Eastern European Harm Reduction Network (CEEHRN). Injecting drug users, HIVIAIDS treatment and primary care in Central and Eastern Europe and the former Soviet Union: Results of a region-wide survey. Vilnius: CEEHRN; 2002.

13. Gowing L, Farrell M, Bornemann R, Ali R. Substitution treatment of injecting opioid users for prevention of HIV infection [Cochrane review]. In: The Cochrane Library (Issue 4). Chichester (UK): John Wiley \& Sons, Ltd.; 2004.

14. Strathdee SA, Palepu A, Cornelisse PG, Yip B, O'Shaughnessy MV, Montaner JS, et al. Barriers to use of free antiretroviral therapy in injection drug users. FAMA 1998;280:547-9.

15. Wood E, Montaner JS, Bangsberg D, Tyndall MW, Strathdee SA O'Shaughnessy MV, et al. Expanding access to HIV antiretroviral therapy to marginalized populations in the developed world. AIDS 2003;17:2419-27.

16. Celentano DD, Galai N, Sethi AK, Shah NG, Strathdee SA, Vlahov D, et al. Time to initiating highly active antiretroviral therapy among HIV-infected injection drug users. AIDS 2001;15:1707-15

17. Moatti JP, Carrieri MP, Spire B, Gastaut JA, Cassuto JP, Moreau J. Adherence to HAART in French HIV-infected injecting drug users: the contribution of buprenorphine drug maintenance treatment. AIDS 2000;14:151-5.

18. Turner BJ, Laine C, Cosler L, Hauck WW. Relationship of gender, depression, and health care delivery with antiretroviral adherence in HIV-infected drug users. 7 Gen Intern Med 2003;18:248-57.

19. Palepu A, Horton NJ, Tibbetts N, Meli S, Samet JH. Uptake and adherence to highly active antiretroviral therapy among HIV-infected people with alcohol and substance use problems: the impact of substance abuse treatment. $A d-$ diction 2004;99:361-8.

20. Wall TL, Sorensen JL, Batki SL, Deluchi KL, London JA, Chesney MA. Adherence to zidovudine (AZT) among HIV-infected methadone patients: A pilot study of supervised therapy and dispensing compared to usual care. Drug Alcohol Depend 1995;37:261.

21. World Health Organization, UN Office on Drugs and Crime, Joint United Nations Programme on HIV/AIDS. Substitution maintenance therapy in the management of opioid dependence and HIV/AIDS prevention [position paper]. Geneva: WHO; 2004: Abstract available: www.who.int/substance_abuse /publications/en/PositionPaper_flyer_English.pdf (accessed 2005 Feb 1).

22. Ball AL, Rana S, Dehne KL. HIV prevention among injecting drug users: responses in developing and transitional countries [review]. Public Health Rep 1998;113(suppl 1):170-81.

23. World Health Organization. Essential medicines: WHO model list (revised April 2003). 13th ed. Geneva: WHO; 2003. Available at: www.who.int/medicines /organization/par/edl/expcom13/eml13 en.pdf (accessed 2005 Feb 1).

24. Kerr T, Wodak A, Elliott R, Montaner JS, Wood E. Opioid substitution and HIV/AIDS treatment and prevention. Lancet 2004;364:1918-9.

25. Charter of the United Nations, 26 June 1945 (entered into force 24 October 1945), T.S. 993, Articles 55 \& 56.

26. Universal Declaration of Human Rights, UN General Assembly res. 217A (III), UN Doc A/810 at 71 (1948), Article 25

27. 993 U.N.T.S. 3, entered into force 3 January 1976

28. United States of America. "Thematic Topic: HIV/AIDS in the Context of Drug Use," paper for Intersessional Working Group on Thematic Drug (2nd meeting, 20 October 2004) regarding UN Commission on Narcotic Drugs, 48th Session (2005), on file with the authors.

29. Canada in the world: Canadian foreign policy review. Ottawa: Department of Foreign Affairs and International Trade; 1995: Available at: www.dfait-maeci .gc.ca/foreign_policy/cnd-world/menu-en.asp (accessed 2005 Feb 1).

30. A dialogue on foreign policy: a report to Canadians. Ottawa: Department of Foreign Affairs and International Trade; 2003. Available at: www.dfaitmaeci.gc.ca/cip-pic/participate/dialoguereport-en.asp (accessed 2005 Feb 1).

31. Canada's Drug Strategy. Ottawa: Health Canada; 1998. Available at: www.hc-sc .gc.ca/hecs-sesc/cds/pdf/englishstrategy.pdf (accessed 2005 Feb 1).

32. Reducing the harm associated with injection drug use in Canada. Report prepared by the Federal/Provincial/Territorial Advisory Committees on Population Health, Alcohol and Other Drug Issues, AIDS, and the Federal/Provincial/Territorial Heads of Corrections Working Group on HIV/AIDS, 2001. Available at: www .hc-sc.gc.ca/hecs-sesc/cds/pdf/injectiondrug_e.pdf (accessed 2005 Feb 1).

Correspondence to: Richard Elliott, Canadian HIV/AIDS Legal

Network, 890 Yonge St., Ste. 700, Toronto ON M4W 3P4; fax

416 595-0094; relliott@aidslaw.ca 